\title{
A Comparative Study: Self-Realization in Twentieth- Century Western Thought, Ibn e Arabi's Idea, and Theatre of The Absurd
}

\author{
Bahee Hadaegh \\ Shiraz University, Faculty of Foreign Languages \& Literature \\ School of Literature and Humanity Science, Shiraz, Iran \\ e-mail: bhadaegh@rose.shirazu.ac.ir
}

\begin{abstract}
Following humans' struggles to achieve a better understanding of the self throughout major historical periods, the idea of the quest for a whole self is once more rekindled in the anxiety-laden atmosphere of the twentieth century. However, unlike the previous approaches, the twentieth century reflection of the notion of the quest for self-realization is paradoxically revealed in a new model of struggle which inclines more toward spiritual search. This inward struggle manifests itself through connecting the ego to the unconscious world, in line with the theories of Freud and Jung. The similarity which exists between Jung's psychic state and the Sufis' mystical world defined by Ibn e Arabi, makes it possible to reconsider the seemingly nihilist readings of the quest for self-realization of the twentieth century absurd thoughts in a positive way.
\end{abstract}

Key words: theatre of the absurd, twentieth century, self, Ibn e Arabi, Freud, Jung

Following the modern Spiritualist movement blooming in the nineteenth century, the new model of struggle for self-realization inclines more toward spiritual quest through connecting the ego to the unconscious world, in line with the theories of Freud and Jung. This new movement, according to Webb (1974), reveals "a revival of traditional occultism," focusing on the flight from the world of consciousness and direct access to human inwardness (p. 15). Myers (1903) suggests that this occultist tendency takes on a myth-making function that focuses on the idea of the "subliminal self" (p. 39) and gives rise to the increasing separation of the conscious ego from the individual's world of unconscious in the twentieth century. In a similar vein, Heidegger's notion of "Dasein," and Jung's idea of the "Self" exhibit the quasi-mystic aspect of such a spiritual model in the new era. 
The idea of the quest for a whole self is once more rekindled in the anxiety-laden atmosphere of the twentieth century. As one of the most influential figures of the century anticipating the rise of existentialism, Heidegger clearly reveals the relationship between the anxiety of human beings and their aspiration for the authentic self. Heidegger's specific type of Being (Dasein) which literally means 'Being-there' calls attention to the fact that without experiencing an existential loss, there is no authenticity of being. In Being and Time, Heidegger (1953) postulates, we have a 'Beingin-the-world' Dasein which can exist in two modes, inauthentic and authentic (p. 117). According to Heidegger, this 'Being-in' is an existing state for the authentic Being since the anxiety and the fear which exist in the world lead the individuals to experience all the elements of the inauthentic existence urging them to ask for authenticity.

Very close to Heidegger's idea, Steiner (1970) clarifies the relationship between anxiety and the emergence of authentic being. $\mathrm{He}$ remarks that anxiety is:

that which makes problematic, which makes worthy of our questioning our Being-in-the-world. Angst is one of the primary instruments through which the ontic character and context of everyday existence is made inescapably aware of, is rendered naked to, the pressure of the ontological. And, further, Angst is the mark of authenticity, of the repudiation of the 'theyness' (p. 78).

Considering the antithesis of possessing authentic and inauthentic Dasein as 'oneness' and 'theyness', Heidegger hypothesizes that the state of 'falling-away' or "a cadence into decline" (Verfall) is a positive state where the individual feels the necessity to ascend to the authentic Being:

Dasein has, in the first instance, fallen away [abgefallen] from itself as an authentic potentiality for Being in its self, and has fallen into the world. 'Fallenness' into the world means an absorption in being withone-another, in so far as the latter is guided by idle talk, curiosity, and ambiguity. Through the interpretation of falling, what we have called the inauthenticity of Dasein may not be defined more precisely. On no account, however, do the terms 'inauthentic' and 'non-authentic' signify 'really not', as if in this mode of Being, Dasein were altogether to lose its Being (p. 182). 
Human beings' fallenness into the mundane existence is then a positive state which makes them aware of their inauthentic self urging them to strive for an authentic Being. In other words, to give rise to a sense of the uncanny and emptiness which is the prerequisite for the recognition of the self-loss, humans must keep such a frenetic state under control by habitual everydayness, and talk. Thus the anxiety of this bitter recognition must be preserved by the sense of presentness in this fallen condition. Heidegger explains such a strategy this way:

When Dasein understands uncanniness in everyday manner, it does so by turning away from it in falling; in this turning away, the 'not at home' gets 'dimmed down'. Yet the everydayness of this fleeting shows phenomenally that anxiety, as a basic state of mind, belongs to Dasein's essential state of Being-in-the-world, which, as one that is existential, is never present-at-hand but is itself always in a mode of facticial Being-there-that is, in the mode of a state of mind (p. 198).

Heidegger believes that to meet a complete self-fulfilment, anxiety forces the human beings towards the freedom that death suggests. Such an opportunity changes anxiety to a feeling of certainty which foreshadows final attainment of the authentic self. Heidegger finally states:

Death is a possibility-of-Being which Dasein itself has to take over in every case. With death, Dasein stands before itself in its ownmost potentiality-for-Being. This is a possibility in which the issue is nothing less than Dasein's Being-in-the-world. Its death is the possibility of no-longer being-able-to-be-there. If Dasein stands before itself as this possibility, it has been fully assigned to its ownmost potentiality-for-Being. When it stands before itself in this way, all its relations to any other Dasein have been undone. This ownmost non-relational possibility is at the same time the uttermost one (p. 219).

The self-releasing nature of the phenomenal falling, the forlornness, anguish and despair of humanity which twentieth-century existentialism advocates, can be also positively interpreted under the light of Heidegger's Dasein's Being-in-the-world. In this way, Heidegger's paradoxical notion of emptiness and fullness is reminiscent of Nietzsche's paradox of self- 
forgetfulness and self-liberation in the nineteenth century. This kind of negative affirmation which is both manifest in Dionysian self-suspension and Heideggerian severe self-reduction and non-relation echoes the negative teachings of apophatic theology and mysticism. In a similar way that tragic self-destruction is blissfully endured by the Dionysian individuals, the idea of death offers freedom from the uncertainty and anxiety of the inauthentic being in Heidegger's idea. However, while Dionysian self-suspension is accomplished through merging of the individuals' ego with the elements of nature as the source of meaning, the transformation of inauthentic Dasein to authentic Being is accomplished through the ego's own state of loss which mystically turns to transcendence. In Heideggerian theory then, self-transcendence takes place through dissolution of the ego by putting itself in the process of gradual loss, while Dionysian transcendence occurs through the chaotic transmutation of the ego to nature.

While the twentieth-century definition of the Self provided by Jung reflects Nietzsche's idea of the 'Ubermensch' and the quest for wholeness, Jung's approach inclines more towards the spiritual side of dissolution, focusing on the transmutation of the ego to the world of unconscious. His notion of the Self represents a sustained attempt to elevate the human being, an idea he inherited from the previous century. As discussed earlier, Nietzsche's 'Ubermensch' emphatically focuses on the Dionysian notion of the whole self. In Nietzsche's project, individuals are supposed to achieve the whole self through uniting with nature so as to be redeemed and saved from the moral doctrines of the time which repress their instincts. The Dionysian individuals thus promote the "natural body" as Nietzsche (1999) remarks in the prologue of Thus Spoke Zarathustra (p. 1).

Nietzsche's naturalized individuals who try to attain a higher self through taking shelter into nature, intoxication, madness, art, love, literature, and blissful endurance of suffering, reflects Nietzsche's idea of the unification of body and spirit, joy and sorrow, creation and destruction. Dionysian individuals, then, are those who are reunited with the essence of humanity and whatever is passionate, irrational, and chaotic in themselves. They blissfully and tragically demolish the ego to restore themselves to the humanizing spirit of nature and "experience an ascent-up" into a high and free naturalized self (Nietzsche, 1967, p. 120).

Jung's "Individuation" is the term he applies to describe the individuals' instinctive search for a whole self in the twentieth century. His 
image of the whole self as "Mandala", "ring" or "circle" shows his extensive adaptation of Nietzsche's Dionysian Eternal Recurrence representing the idea of the whole self (Nietzsche, 1999, p. 191). However, unlike Nietszche's vigorous promotion of the "natural body" through passionate unification with natural elements, Jung's focal point is more spiritual. Since Jung considers God as a unifying guide in the depth of the unconscious, his idea of the 'Self' is more internal and immaterial. As Huskinson (2004) observes, Jung maintains that Nietzsche's Ubermensch promotes the 'natural body' too vigorously, so that it over-identifies with the material and does not adequately support its spiritual opposite, God (p. 96). Jung's 'Self' is the centre and summation of unconscious, correlating more with the metaphysical notion of self awareness symbolized in the idea of atman (the immortal aspect of the mortal existence; it is the very self, the microcosm which imparts to us divine qualities) in the East. Unlike Ubermensch's destructive unification with nature, via escapist rapture, Jung advocates using one's active imagination as the method by which one can gradually bring the unconscious to the surface without either destroying or inflating the ego in the process of transcendence.

Jung's idea of active imagination is the development of Freud's notion about the relationship of dreams with eternal existence. The psychology of thought in the Freudian system which focuses on the topics of feeling, emotion, and memory already reflects the crucial role of the personal unconscious. This way, imagination comes to actualize the abstract, outside world followed by the idea of the role of such an imaginative actualization. Freud brings forth a new method of presentation for human's insight in a different field of human activity.

Very close to the function dream has in manifesting the absolute, fantasy plays its role, according to Rosemary Jackson's (1981) Marxist and Freudian view, "In expressing desire, fantasy can operate in two ways, it can tell us or manifest desire or it can expel desire, when this desire is a disturbing element which threatens cultural order and continuity" (p. 17). Tolkien (1975) maintains that: "fantasy is a means of setting needs and desires free, confirming the validity of their pursuit and fulfillment, presenting the recovery of fragmented or lost desires and offering consolation" (p. 20). Comparing Nietzsche's Dionysian method of selfrealization to that of Jung, I agree with Jackson's idea about the doubleedged nature of dream and fantasy. In Nietzsche's Dionysian approach of the quest, fantasy acts as an agent for creating various manifestations of the 
wished-for self while in Jung's imaginative action it expels any desire and exposes the ego to the spiritual world of the unconscious.

Redefining the notion of the Self, Jung focuses on its ideal potency where the Self is actively able to generate images which it should ideally become. The unconscious is thus a permanent given that is the main transforming agent of the ego. Taking this into account, Jung identifies the Self with the traditional religious representations like the Ultimate or Absolute. In his radical consideration, the Self is indistinguishable from God, Christ, Buddha or Khisr. Jung's reified 'other' within the very depths of the unconscious considers the ego as a distinct entity from the subjective activity of the individuals. Similar to Hegel's idea of the "spirit" discussed in the Phenomenology of Mind where he forestalls the alienation of the ego through appealing it to its other dimension, in Jung's idea of the reified ego, finding one's authentic self demands the alienation of the ego from the Self. In such an intrapsychic affair, personalization of the individuals is an internal process negating the conscious dimension of the ego. This intrapsychic process considers the ego only as an agent which monitors, experiences, and remembers the contents of the dreams in the unconscious world. It is through the journey of the ego which the consciousness is formed and elevated with the treasures brought from the underworld of the unconscious. Here, the Self is also considered as an agent of realizing the ideal which is in need of the stimulus of the ego for self-perfection. Parallel to the intrapsychic pattern of self-realization which is an internal process, there is also an indifference to the world of nature as the source of meaning unlike Nietzsche's emphasis on union with the natural. In Jung's idea of individuation, the source of value is within the unconscious world as an idealizing agent.

The psychic state which is produced as the result of interconnection of the ideal world of the unconscious and the conscious ego is reminiscent of the Sufi mystical world. As Corbin (2007) observes, in the Book of Ophanies, the great mystic Ibn Arabi describes "the intermediate suprasensory world where the Active Imagination perceives events, figures, presences directly, unaided by the senses" (p. 43). Similar to Jung's intrapsychic affair which is indifferent to the outside world, the process of active imagination is also free from the sensual world in mystical revelation of the self. The mystic, as Halligan (2002) believes, thus surrenders the ego in the state of annihilation which gives him the permission to let go of the illusion of separateness and to perceive the unity underlying all life ( $\mathrm{p}$. 
278). According to Halligan "what Jung might call the Collective Unconscious, is essentially the realm of the Active Imagination of [the Sufi] Ibn Arabi" (p. 277).

The imaginal world in both mystic and Jungian models links the opposite world of matter with spirit through the annihilating space that the vision creates. As Jung interprets the entrance of the individuals into the meaningful world of the unconscious as a journey, Ibn Arabi's Journey to the Lord of Power basically concerns the travel of the human beings to the world of vision (as cited in Halligan, 2002, p. 277). He also describes the state of the intuitive individuals as: "the intuitive person sees in his waking state what the sleeper sees in the state of sleep and the deceased after death" (p. 278). The recurrent mystical motif of the union of opposites which leads the mystics to the manifestation of the ultimate truth is reminiscent of Jung's psychic experience. Ibn Arabi's idea of Sophia aeterna which demonstrates the union of the male mystic with God as his beloved is reflected in the image Anima in Jung's psychic state (p. 285).

According to the mystical belief of Ibn Arabi, it is in the interface of such a union ["interval"] where the intuitive person reaches a sense of selffulfilment. Jung similarly approves of such satisfaction by referring to the release of psychic energy in the moment of the union of the opposites. The sense of fulfilment which the intrapsychic affair produces is according to Jung the manifestation of a higher self. Evaluating this transcending moment, Steiner (1970) says: "In certain altered states of consciousness ... one finds a subliminal self or subject, an inner figure who is not the ego but shows intentionality and will. The ego can enter into dialogue with this other subpersonality" (p. 98). Jung's psychic space which takes place in the total surrender of the will throws light upon his mystic aspect of selfrealization. In other words, the surrender or annihilation of the will which occurs in the psychic state, leads to a higher level of realization which Corbin refers to as the moment of presence in mystical experience. Annotating the mystical approach of Ibn Arabi in his active imagination, Corbin (2007) writes:

The mode of presence conferred by the imaginative power . . . is by no means an inferior mode or an allusion; it signifies to see directly what cannot be seen by the senses, to be a truthful witness. The spiritual progression from the state of simple believers to the mystic state is accompanied through an increasing capacity for making 
oneself present to the vision by the imagination ... progressing from mental vision by tipification . . . by way of dream vision . . . to verification in the station of imagination witnessing vision [which] ... becomes vision of God by Himself, the heart being the organ, the 'eye' by which God sees Himself (p. 23).

The fact that the mode of presence cannot take place through the senses makes the intuitive person annihilate the ego which prepares the ground for the appearance of unconscious images during the wakefulness. Through annihilating the senses, the individuals cross over the material world and are increasingly surrendered to the world of spirit which is transmuted and concretized in the shape of visions. Therefore, based on what Jung and the mystics believe about annihilating the senses, the phenomenal world is turned to be illusory itself very close to the nature of the unconscious world. In this regard, along with the twentieth-century idea of the void advocated by Camus' or Sartre's existentialism, the meaningful empty space which is produced following the transmutation of the individuals' consciousness to the spiritual world of the unconscious reveals the quasimystic dissolution of the ego towards attaining the whole self.

One of the manifestations of this quasi-mystic, nirvana-like search for the whole self in the twentieth century is the Theatre of the Absurd. What the saintly hermit in the forest replies to Zarathustra demonstrates the culmination of the traditional occultism which focuses on the individual's alienation of the ego through appealing to its other dimension. When Zarathustra asks the old man how he passes his time in his solitude, he replies: "I make up songs and sing them; and when I make up songs I laugh, I weep, and I growl; thus do I praise God" (II. 279). Although Zarathustra declines the hermit's offer, in private, he speaks to himself this way: "Can it be possible! ..." (Nietzsche, 1999, p. 279).

Following the spiritual nature of the ideas which focus on the transmutation of the ego to the unconscious world early in the twentieth century, the Absurd Theatre paradoxically reveals symptoms of a quasimystic quest for self-realization. While the existentialistic parallels may be informative, the particular richness of the mystical signs in the Absurd plays opens opportunities for positive interpretations. Making songs, singing, laughing, weeping, and growling exemplify the timid effort of the Absurd characters to transmute the ego to the spiritual world of the unconscious through expelling the egoistic desires. The hermit's seclusion 
in a similar vein suggests the purposeful attempt of the individuals to become unaware of the surrounding world and connect themselves to the spiritual world of the unconscious in search of a dimension of the spirituality.

The radical devaluation of language, reliance on dream, fantasy, and memory, lack of communication, irrelevancy of speech, and addiction to silence are all instruments which take the individuals from the conscious world to the spirituality of the unconscious. Inaction is the keynote to the whole process of transmutation as it cuts off the relation of the individuals from the meaningless void of the surrounding reality. Plunging the characters into the passivity of waiting, Godot is the symbol of illusion and inaction who takes the characters back into the spiritual world of the unconscious in the Absurd Theatre.

Being a Jungian psychologist, Metman (1960) also asserts that "Godot's function seems to be to keep his dependents unconscious" (p. 51). The idea is emphasized in Godot when the characters who are about to realize they have been dreaming and must wake up are suddenly faced with the arrival of Godot's messenger who plunges them again into the world of illusion (p. 60). Throughout the whole play, the characters are journeying from the conscious world of the ego to the spiritual world of the unconscious. The characters' persistent devotion in a similar vein paralyzes their consciousness which aims to enable the individuals to enter the realm of essential being. In some of the absurd plays, the characters are even demonstrated to start the play at the level of the unconscious. The characters' paralysis is reminiscent of Heidegger's idea of the necessity of recognizing the self-loss through keeping a frenetic state of habitual everydayness, and idle talk. Such an ability is reminiscent of what Beckett (1931) calls the substitution of the "boredom of being" to the "suffering of being" (p. 8). He implies the attainment of the authentic self through paralyzing the individual's consciousness: "The suffering of being: that is the free play of every faculty. Because the pernicious devotion of habit paralyses our attention, drugs those handmaidens of perception whose cooperation is not absolutely essential" (p. 9).

The idea of paralyzing the attention connotes the transmutation of the consciousness to the spiritual world of the unconscious. This kind of transmutation is remarkably manifest in Beckett's allusion to Bram's painting. He explicitly refers to the relationship between non-relation and the idea of fruitful univocity when he writes: 
If I say that he paints the impossibility of painting, the deprivation of relation, of object, of subject, I appear to put him in relation with this impossibility, with this deprivation, in front of them. He is inside them, is this the same thing? He is them, rather, and they are he (p. 82).

According to Uhlmann (2006), Beckett's illusion clarifies "the notion of non-relation" which "necessarily involves the bringing to the light of the univocity of Being" (p. 14). He then explains Beckett's consideration this way: "Once all links are severed paradoxically all runs together becoming indivisible" (p. 14). Uhlmann also relates such disjunction to a quasireligious experience where the body is emptied of all conscious thought and perception. He argues:

The first kind of apprehension (the isolation of a singular object) opens the way to the second kind of apprehension (sensation in the absence of all choice) admitting all possibility and so having done with the possible, renouncing all possible action for: 'Our representation of matter is the measure of our possible action upon bodies: it results from the discarding of what has no interest for our needs, or more generally, for our functions' (Bergson, 1991:38). The renunciation of this perception, then, involves the abandonment of all possible relation, dissolving one's own identity in merging with all Being (p. 76).

The influence of the idea of non-relation is manifest in all Beckettian characters and those represented by Pinter. Paralyzing the conscious ego, Pinter's characters reach the climactic point of transformation where they regressively move from the superficial ego to the preliminary stage of selfhood. Begley (2005) takes Pinter's Betrayal as an example and explains such a psychological movement this way: "This idea is that regression allows a return to early life experiences that connect the divided self to its underlying truth or origin" (p. 132). In this play, the characters' selfparalyzing experience easily separates them from the conscious world and lets them enter the level of the unconscious.

There is remarkably a close affinity between the process of transformation in Pinter's characters and those of Beckett. It is accomplished through similar devices like the showing up of speech 
represented in the characters' silence and deliberate evasion of communication. Begley's idea about psychological movement through which the divided ego is connected to the underlying origin of all reflects Jung's quasi-mystic idea of transmutation of the ego to the spiritual world of the unconscious.

Uhlmann (2006) reveals the mystical aspect of such a transmutation when he refers to the merging of the finite with the infinite side of the individuals. His idea of merging the finite with the infinite is reminiscent of Jung's quasi-mystic notion of individuation transmuting the consciousness to the spiritual unconscious:

In turn, requires a merging again with the plane of immanence, the univocity of Being which is Spinoza's one substance. This occurs through a process of inclusive disjunction whereby the modes are at one and the same time finite or individuated and merging with the infinite substance within which they are no longer individuated, (that is, there is a disjunction through which a mode is individuated, but that disjunction is inclusive so that it remains indistinguishable from the substance from which everything emerges. Alluding to Beckett's phrase in Malone Dies, 'everything divides ...into itself', Deleuze states: "The disjunction has become inclusive, everything divides, but within itself, and God, who is the ensemble of the possible, intermingles with Nothing, of which each thing is a modification (p. 13).

The twentieth-century experience of transmutation of the ego to the world of the unconscious expresses the unending tradition of the quest for the authentic self through an inward, inactive approach. The recurrent mingling of dream and reality along with the ceaseless mental argument focusing on inwardness and immobility terminates the idea of futile preoccupation with the false alluring of the outward world and the continuous effort towards expelling any desire. This recurrence also prevents the catastrophic failure of the questers in the light of a situation that everlastingly repeats itself.

While Nietzsche's Dionysian pattern of the quest passionately asks for chaotic dissolution of the ego through ecstatic merging with the spirit of nature as the source of meaning, the spiritual transmutation of the ego to the world of unconscious demands a persistent inwardness, implying a kind of order or spiritual peace, as Clov represents it in Beckett's Endgame 
(1962): "I love order. It's my dream. A world where all would be silent and still and each thing in its last place, under the last dust" (p. 57). Clov's silent world reflects the completely spiritual or quasi-mystic notion which emphasizes that there is no need to pursue any other alternative. Such stillness signifies the final recognition of the positive nothingness which represents itself in Beckett's (1987) favorite quotation: "Nothing is more real than nothing" (p. 193).

In other words, as Bataille (2004) reveals, the dissolution of the ego in Nietzsche's Dionysian rapture (p. 177) ends in a dangerous destruction which despite being blissful only foreshadows self-liberation after death. The imaginative world and fantasy-laden atmosphere of the nineteenthcentury Dionysian quest is shattered by the phenomenal reality of the outside world. The suspension of the ego is transitory as the source of meaning is shared between the mind of the questers and nature. On the other hand, the individuation of the twentieth century focuses on the interrelationship between the conscious ego and the buried layers of the self itself as the source of meaning. The quasi-mystic renunciation of the ego through its recurrent transmutation to the world of unconscious promises the hopeful manifestation of self-realization without any dangerous end. The attempt at spiritual transmutation to the unconscious world, which is the dominant spirit of the twentieth-century idea of the quest for selfrealization, demonstrates a meaningful emptiness of nirvana leading to the manifestation of authenticity without the death of the questers. The Theatre of the Absurd is one of the expressions of such a quasi-mystic emptiness conveying the idea of self-nullification and self-realization.

Some might think that the self-nullifying actions of the characters of the Absurd Theatre prevent theatre from harboring any tragic sense. Referring to what Roche believes about the definition of tragedy and the conscious attempts of the absurd dramatic characters to annihilate the ego, we can consider the Theatre of the Absurd to be a continuation in the developmental process of Western tragedy rather than a deviation from it. Defining tragedy based on the notion of the hero's greatness, Roche (1998) asserts that "the various forms of greatness, which can be viewed dialectically, allow us to speak of different types of tragedy" (p. 49). He adds that "the initial form we see [is] a tragedy of self-sacrifice. The hero does good knowing that she will suffer for it" (p. 49).

The conscious self-renunciations of the absurd dramatic characters lead them to an ongoing substratum of suffering which can be considered 
to be a kind of self-sacrifice in the quest for greatness. Although based on the weakness of the modern dramatic characters in coping with the absurd situation, Roche distinguishes between tragedy and the twentieth-century drama of suffering, as the characters try to attain their wished-for higher self; they are still great and not submissive to the circumstance.

The fact that self-annihilation and complete withdrawal from the allures of the outside world are the only possible choices left for the absurd dramatic characters to challenge the finitude of the environment in order to achieve the wished-for greatness, makes it possible to consider them as great as Oedipus, whose self-imposed blindness at the end of his quest for self-realization led him to an inward insight.

The tentative calmness that the absurd tragic characters feel, either during the moments of suffering or after the whole process of suffering, once more justifies the type of tragedy which the Theatre of the Absurd can suggest. The sense of mild happiness or the internal rejoicing that can be recognized in the absurd characters is reminiscent of Schelling's notion of tragic sacrifice where "precisely at the moment of most sublime suffering the tragic hero enters into the most sublime liberation and most absence of suffering" (as cited in Roche, 1998, p. 52). Here, Schelling's idea well reflects the quasi-mystic nature of the Theatre of the Absurd, where the conscious self-renunciation of the characters are reminiscent of the Sufi's rapturous self-annihilating actions which lead them to attain a higher degree of self-realization. The idea is also applicable to the Jungian reading of the Theatre of the Absurd where the transmutation of the ego makes the individuals enter the spiritual world of the unconscious. The idea also matches a Nietzschean interpretation of the Theatre of the Absurd where tragic suffering is happily welcomed by the Dionysian individuals to make them attain a higher self.

From another view point, based on Scheler's (1991) definition of tragedy reflected in "On the tragic," whatever leads to greatness and allows the hero to realize a positive value also engenders suffering (p. 29). The idea is reminiscent of Icarus of the Classical mythology whose ascent was supposed to give him a sense of a higher self, but the glue that held his wings led him to suffering and his final fall. Therefore, in this context, the suffering must not necessarily stem from the hero's greatness. It can stem from the attempt towards greatness.

Considering either of these suppositions, whether the absurd dramatic characters are great themselves because of their heroic self-annihilating 
attempts or their endeavors towards achieving greatness, based on the tradition of the quest for self-realization, the Theatre of the Absurd can be considered as a continuation of the process of development in Western drama. It might be better to consider it as a specific kind of tragedy in twentieth-century plays where the characters take benefit from the only possible option left for them in the meaningless absurd world.

\section{REFERENCES}

Bataille, G. (2004). On Nietzsche. London: Continuum International Publishing Group.

Beckett, S. (1962). Endgame. London: Faber and Faber.

Beckett, S. (1931). Proust. London: Grove Press.

Beckett, S. (1987). Waiting for Godot. H. Bloom, (Ed.). New York, NY: Chelsea House Publishers.

Begley, V. (2005). Harold Pinter and the twilight of modernism. Toronto: University of Toronto Press.

Corbin, H. (2007). Creative imagination in the sufism of Ibn Arabi. London: Taylor $\&$ Francis.

Halligan, F.R. (2002). The creative imagination of the Sufi mystic, Ibn 'Arabi. Journal of Religion and Health, 40 (2), 275-289.

Heidegger, M. (1953). Being and time. (J. S. Albany, Trans.). New York, NY: State University of New York Press.

Huskinson, L. (2004). Nietzsche and Jung: The whole self in the union of opposites. Brunner: Routledge.

Jackson, R. (1981). The literature of subversion. London and New York: Routledge.

Metman, E. (1960). Reflections on Samuel Beckett's plays. Journal of Analytical Psychology. 5 (1), 41-63.

Myers, F. W. H. (1903). Human personality and its survival of bodily death. (Vols. 1-2). London: Longmans Green.

Nietzsche, F. (1967). The will to power. (W. Kauffman \& R.J. Hollingdale, Trans.). New York, NY: Vintage Books.

Nietzsche, F. (1999). Thus spoke Zarathustra. London: Dover Publications, Inc.

Roche, M.W. (1998). Tragedy and comedy: A systematic study and a critique of Hegel. New York, NY: Suny Press.

Scheler, M. (1991). On the tragic. In A. Coffin (Ed.), The question of tragedy. San Francisco: Edwin Mellen Press.

Steiner, G. (1970). Heidegger. Sussex: The Harvester Press.

Tolkien, J. R. R. (1975). On fairy stories. London: Tree and Leaf.

Uhlmann, A. (2006). Beckett after Beckett. Florida: University Press of Florida.

Webb, J. (1974). The occult underground. Open Court Publishing Company. 